\title{
Аліна Сабуць
}

Гродзенскі дзяржаўнь уัніверсітэт

\section{Нацыянальна-культурны кампанент і міжкультурная камунікацыя}

У працэсе міжкультурнай камунікацыі адметная роля належыць менавіта мастацкаму перакладу. Да актуалізацыі праблемы перакладу як культуралагічнай з'явы вучоныя розных краін звярталіся не аднойчы. Кантэкстуальнае вывучэнне слова (сінтэз моўна-стылявых, культурна-эстэтычных адзінак) у мастацкім творы ўскладае пэўную адказнасць на перакладчыка. Так, на думку расійскіх даследчыкаў Л.К. Латышава і А.Л. Сямёнава, пераклад - гэта не толькі замена мовы, але $і$ функцыянальная замена элементау культуры ${ }^{1}$. Паводле вядомага грузінскага вучонага-перакладчыка, паэта Г.Р. Гачэчыладзе, які яшчэ у 70-я гады XX-га стагоддзя акцэнтаваў увагу на нацыянальнай спецыфіцы завершанага перакладу, у перакладзе выяуัляецча наџыянальная адметнасиь творчасиі самога перакладчыка ${ }^{2}$; праблема начылнальнай спецыфікі мастацтва чесна судакранаециа з праблемай народнасиі, апошняя ж рацыю балгарскі даследчык Г. Лілова, якая ӱ развагах пра дыялектыку нацыянальнага і інтэрнацыянальнага у перакладзе заўважыла, што задача кожнага перакладчыка - знайсці $i$ асэнсаваџь сутнасць начыянальна адметнага і спечьфічнага; правільная перадача гэтых

1 Л. К. Латышев, Перевод: теория, практика и методика преподавания, Москва 2003, c. 108.

2 Г. Гачечиладзе, Художественный перевод и литературные взаимосвязи, Москва 1980, с. 147.

3 Тамсама, c. 149. 
элементаў нацьянальнага адкрывае шлях і для выяўлення інтэрначьлянальнага ў творы; ва ўдальм перакладзе спецьфічная, самабытна-наивиянальная аснова твора не прападае, $і$ іменна ў гэтым бачыциа адзін з асноўных прынцыпай творчай перакладчьцкай дзейнасчі ${ }^{4}$. Урэшце, трэба пагадзіцца са словамі нямецкага пісьменніка I.P. Бехера: $C m в a-$ рэнне высокай культуры перакладу садзейнічае росту начьянальнай літаратуры $і$ ўсведамленню ёю свайго начьинальнага характару5.

Такім чынам, мастацкі пераклад - найбольш рэпрэзентатыўны від кантакту (дыялогу, палілогу) паміж нацыянальнымі літаратурамі. Заўважым, толькі на пачатку 90-х гадоў XX-га стагоддзя ў айчынным перакладазнаўстве пераклад пачынае разглядацца як дзейсны нацыяўтваральны фактар ${ }^{6}$. Сярод беларускіх даследчыкаў тэорыі і практыкі мастацкага перакладу адносна вышэйзгаданага пытання варта назваць працы Міхася Кенькі, Вячаслава Рагойшы, Івана Чароты, Наталлі Дзянісавай, Алены Таболіч, Святланы Скамарохавай, Ганны Старасцінай і інш. У зведанай беларускай сітуацыі з ілюзорнай самаізаляванасцю, засяроджанасцю толькі на сабе дылема сваё/чужое (як замежнае) якраз слаба спрыяла ўстойліваму статусу беларускага нацыянальнага менталітэту, светааадчування, урэшце, збядняла яе ӱнутраныя патэнцыі. Невыпадкова апошнім часам у беларускай кампаратывістыцы заявілі пра сябе праблемы інтэрпрэтацыі перакладчыка як сааўтара, праблема рэцэпцыі. У гэтай сувязі вядомы беларускі кампаратывіст, аўтар навуковых прац па славістыцы, чэшскай літаратуры, сусветнай літаратуры ХХ-га стагоддзя Ірына Шаблоўская справядліва адзначала: Мусім прызначь, што энергія літаратурнага ўзаемадзеяння на Беларусі ледзьве адчувальная. Мала перакладалася на беларускую мову твораў сусветнай класікі, фрагментарна прадстаўленыл на ёй літаратуры свету, як заходнія, так і ўсходнія, выключэннем з'яўляециа, бадай што, літаратура руская... Беларуская сітуачыя, такім чынам, сведчыць пра абмежаванасць успрынячия літаратурь сусветнайт.

Насамрэч, каб сцвердзіць, што беларуская літаратура - сапраўды нацыянальная еўрапейская з'ява, неабходна ўсвядоміць: якое ж месца

4 А. Лилова, Введение в общую теорию перевода, Москва 1985, с. 103-104.

5 И. Р. Бехер, О литературе и искусстве, Москва 1981, с. 93.

6 В. Рагойша, Пераклад як нацьяутваральнь фактар, "Беларусіка = Albaruthenika", кн. 1, Мінск 1993, с. 225-230.

7 I. В. Шаблойская, Сусветная літаратура ў беларускай прасторы: Рэџэпџьля. Тыпалогія. Кантакты, Мінск 2007, с. 19. 
адведзена беларусу ў пасадзе між еўрапейскімі народамі? Недарэмна і своечасова падчас нашаніўскай дыскусіі 1913 года ставілася праблема еўрапеізацыі-самабытнасці беларускай літаратуры. Невыпадкова ж паэт-эстэт Максім Багдановіч дбаў, каб надаць беларускай паэзіі больш еўрапейскага выгляду, але не сумняваўся ў тым, што і еўрапейская паэзія мае беларускае адгалінаванне. Сапраўды, разглядаючы літаратуры з рознымі генетычнымі, тыпалагічнымі і кантакталагічнымі адметнасцямі, варта згадаць пра непадробную паэтыку верленаўскага верша $\ddot{\mathrm{y}}$ М. Багдановіча, дантаўскія алюзіі $\ddot{\mathrm{y}}$ твоpax Я. Купалы, найдасканалейшыя дубойкавыя пераклады санетаў У. Шэкспіра, праметэізм М. Танка, беларускі варыянт постмадэрнізму. Адзін з заснавальнікаў беларускай школы мастацкага перакладу Я. Семяжон мае багаты творчы вопыт: пераклад твораў з літаратур на 34-х мовах свету. Сёння нашы суайчыннікі могуць хваліцца цудоўнымі перакладамі з Байрана, Гётэ, Дантэ. Майстра-віртуоз, аўтар намінаванай на Нобелеўскую прэмію кнігі "Ксты" (2005), выдадзенай па-беларуску і па-ангельску, якую рэдагавалі эксперты з Велікабрытаніі і ЗША, Р. Барадулін перастварыў Святое Пісьмо. Вера Рыч і Ў олтэр Мэй стварылі паэтычныя англамоўныя анталогіi, дзе самавіта выяўляецца краса $i$ сіла беларускай паэзіi.

Пераклад набывае не толькі мастацка-эстэтычную, але і камунікатыўную ролю. Так, пры кантэкстуальным вывучэнні літаратуры (калі параўнойваць праўдзіва параўнальнае $\ddot{y}$ творы і ўмець бачыць "нацыянальнае" $\ddot{\mathrm{y}}$ ім) мэтазгодна ўлічваць, што пэўная нацыянальная літаратура ўтрымлівае сваю ўнутраную стадыяльнасць развіцця, уласную спецыфіку светаадлюстравання. Кожная нацыя мае сваю развітую мастацкую сістэму, свой Нацыянальны Космас. Як і пераклад - сваю культуру творчасці (на мяжы мастацка-даследчыцкай). Праблема перадачы "нацыянальнага", ці т.зв. глыбокая нацыянальнасць перакладу абумоўлены, зразумела, канкрэтна-нацыянальным выяўленнем ці т.зв. нацыянальна-культурным кампанентам. Не апошнюю ролю маюць і сітуатыуныя рэаліі, якія вымагаюць дастатковага ведання народных звычаяў (прыкмет, правіл народнай этыкі), а таксама асаблівасцяў светаўспрымання таго ці іншага народа, ягонай эстэтычнай іерархіі каштоўнасцяў. Як вядома, ноч ва ўспрыманні еўрапейца - гэта пэўныя асацыяцыі са сном, холадам, цеменем, нават са смерцю; для ўсходніка ж ноч суладная са згарманізаваным супакоем, наталеннем, амаль што хараством. Згаданае абумоўлена розным сэнсам, укладзеным у эстэтычнае светаразуменне кожнага народа, таму падобныя сітуатыўныя рэаліі вымагаюць ад перакладчыка пэўнага 
каментару. Так, пра рэаліі чужой культуры, нярэдка палярныя тыпы разумення жыццёвых каштоўнасцяў і адпаведнай ім сімволіцы, даследчык I.C. Аляксеева пераканаўча гаворыць:

(...) представители разных культур, за плечами которых разный исторический и социальный опыт, понимают свободу по-разному. Резко отличаются представления о свободе у американца, русского, немца и китайца. Например, для русского человека свобода - это в первую очередь отсутствие каких бы то ни было обязательств, возможность полностью распоряжаться собой и своим временем, отсутствие внешнего давления; для немца свобода - это прежде всего юридическая гарантированность его прав, чёткая отрегулированность правового механизма, материальная обеспеченность, а русскую "свободу" он считает разгулом. А вот в чукотском языке, как отмечает М.Л. Гаспаров, вообще нет слова "свободный", есть только "сорвавшийся с цепи" (М.Л. Гаспаров, Записи и выписки, М. 2000, c. 57.). Такие случаи часто ведут к недоразумениям при контактах. Если эти контакты устные, то на переводчика, помимо перевода текста, возлагается функция консультанта по межкультурной коммуникации, если же переводится письменный текст, необходимы комментарии или примечания к тексту, инициатором которых выступает переводчик. Подобную проблему составляет особое символическое толкование некоторых обычаев разных народов. Например, обычай снимать обувь перед тем, как войти в дом на Востоке, скажем в Узбекистане, считается проявлением уважения к хозяину; у большинства европейских народов такого обычая нет, и вполне прилично пройти в дом в обуви. И здесь переводчик может помочь избежать недоразумений, пояснив своим подопечным смысл обычаев, если он гид-переводчик, или же предложив свой комментарий к письменному тексту, если описывается обычай, непонятный читателям переводного текста ${ }^{8}$.

Безумоўна, нацыянальны каларыт твора перадаецца не толькі праз спецыфічнае бачанне народам тых ці іншых рэалій. Нацыянальна-культурны дух твора ўвасабляе панарамную нацыянальную прастору $з$ адметнай моўнай рытміка-меладычнай кампазіцыяй. Так, англійскае паэтычнае слова надзвычай лірычнае, беларускае ж - эпічнае, "густое". Або, у беларускіх мастацкіх тэкстах як адметны знак нацыянальнай ландшафтнай прасторы - згарманізаванае спалучэнне зямнога і нябеснага, дзе, па-купалаўску кажучы, лунае мой $\partial y x$, ці па-барадулінску, зямля гаворыць з небам курганамі. Спрадвечная беларуская існасць пануе $\ddot{y}$ адметных архетыпах балота, лесу, курга-

8 И. С. Алексеева, Введение в переводоведение, Санкт-Петербург - Москва 2004, c. $11-12$. 
на са спецыфічнымі матывамі сумежнасці-пераходнасці, што аргументавана даследаваў у беларускай літаратуры XX-га стагоддзя праз працэсы нацыянальнага самавызначэння I.А. Чарота ${ }^{9}$. Своеасаблівае мастацкае ўсведамленне меланхалічным, рахмана-інтравертным Хомкам-беларусам праблемы чалавечага духу/характару стала беларускім феноменам двудушнасці (гарэцкаўскае адкрыццё), досыць складаным, а часам супярэчлівым у мастацкім досведзе небеларускага перакладчыка і айчыннага перакладчыка на іншую мову.

Пры перакладзе мастацка-творчы ўплыў жыватворны толькі пры ўмове адчування прыроды мыслення паэта. Безумоўна, не без уплыву сусветнай паэзіі беларускі творца Максім Багдановіч піша свой верш па матывах арыгінала Верлена - паэта млоснасиі, асенняй песні, а не перакладае гэты арыгінал з падрадкойніка, таму што сам добра валодаў французскай мовай, таму што адчуваў Поля Верлена як ні адзін славянскі паэт (слушна заўважыў I. Навуменка). Беларускі чытач пачуў "свайго" Верлена, каб праз гучанне, спей плыннай, цякучай верленаўскай ліры дакрануцца да стомленай, адчужанай, спакутаванай душы французскага паэта. Увогуле ж, у паэтычным свеце М. Багдановіча чуецца рознагалосая музыка, увасобленая праз канцэпты “эмоцыі", “пачуцці", “душа", “сэрца" і інш. Так, словы-канцэпты "душа", "сэрца" у 22-х вершах-перакладах з П. Верлена часта ужжывальныя (каля 30 выпадкаў) для выяўлення-перадачы пачуццяў, бо сам М. Багдановіч спасцігаў боль і самоту спакутаванай душы Верлена: Плач сэриа майго // Як над горадам, дождж10 «цуша твая -

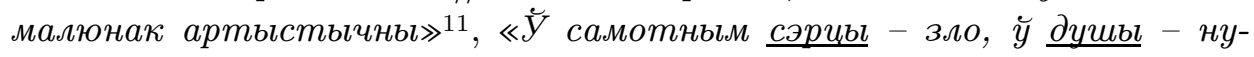
$\partial a$ густая» 12 і інш. Прынагодна згадаем вартую заўвагу беларускага літаратуразнаўцы В. Івашына адносна дыялагічнасці мастацкага мыслення М. Багдановіча: Паэт умеў гльббока суперажььвачь блізкае, роднае сабе ў іншых культурах, знайсці заусеёь там водгук для сваёй душы. Чуласць да “чужога" як свайго, дьялагічнасиь - характэрная асаблівасиь яго паэтыкі, мастацкага мыллення, творчага стымулу i спосабу ўспрымання традыцый 13 . I таму сама гармонія слова і музыкі праз своеасаблівую празрыстасць і вабную недагаворанасць пачуццяў

9 I. Чарота, Пошук спрадвечнай існасці: Беларуская літаратура XX стагоддзя ў праџэсах начьянальнага самавызначэння, Мінск 1995.

10 М. Багдановіч, Пойны збор творай: У 3 т., Мінск 1991, т. 1, с. 174.

11 Тамсама, с. 183.

12 Тамсама, с. 189.

13 В. У. Івашын, У кантэксие мастаикіх культур, “Полымя" 1998, № 12, с. 259. 
у паэтыцы абодвух творцаў ёсць сапраўдная мастацкая з'ява. Больш за тое, беларускі паэт «выбудоўваў» сваю, нацыянальную мадэль паэтычнага імпрэсіянізму, сімвалізму - праўдзівую і непадробную. Прынцып Прыгажосць - вышэй за ўсё! слугаваў яму пры скрупулёзным адборы твораў-перакладаў. Тут Поль Верлен - адзін з самых улюбёных паэтаў, дзе дамінантнай, найвышэйшай бачыцца сама музыкальнасць верша. Насамрэч, паэзія абодвух творцаў грунтуецца на дапытлівым, шукальным сузіранні. Якраз яно - сузіранне - вымушае паэта адвярнуцца ад шэрай жорсткай паўсядзённай рэальнасці, падштурхойвае знайсці-стварыць іншую рэальнасць, дзе пануе зладжаная гармонія, дзе $\breve{y}$ малым, непрыглядным бачыцца велічнае, бясконцае; раскашуе надзвычайнае, учэпістае захапленне жыццём і гэткая кволая неабароненасць перад ім. I колькі разоў ні перачытвай беларускага і французскага паэтаў, усё ж свядомае імкненне да эстэтызацыі, вытанчаная элегантнасць гукавага складу, унутраная гармонія і дасканаласць формы падкрэсліваюць адметнасць аўтарскіх стыляў, хоць, праўда, у кожнага ён свой. У паэтыцы абодвух мастакой слова няма "лішніх" слоў, яны "берагуць" слова, вабнае сваёй экспрэсіяй. Пераклады М. Багдановіча з П. Верлена - узор прыгожага дыялогу двух арыгінальных творцаў, узор захавання свайго стылю, сваёй песні, сваіх зыкаў.

Зусім невыпадковыя творчыя перазовы "самага небеларускага" (Іван Штэйнер) і разам з тым нацыянальна-самабытнага паэта А. Разанава з японскім паэтам Мацуа Басё. Хоку Мацуа Басё ні ў якім разе не "беглыя" экспромты, а найперш глыбокаёмістыя, самасузіральныя мініяцюры з пэўным арнаментальным ушчыльненнем. Паэтычнасць ягоных хоку - у прасвятленні, азарэнні Ісцінай. Гэта найперш кантэкстуальны перазойны дыялог, праўда, пры ўдзеле маўклівых прысутных. Па-першае, тут важная першаснасць эмоцыі і філасофска-інтэлектуальнай заглыбленасць. Праз крышталізацыю прыроднага - да суб'ектыўна-лірычнага. Інтуітыўнае пазнанне свету падкрэслівае ўнутраную відушчасць творчага "я". Трохрадковікі вабныя майстэрствам намёку, стварэннем падтэксту:

Старая сажалка.

Жабка ӱ ваду

скокнула: гук усплёску ${ }^{14}$

14 Цыт. па: Г. Туркоў, Дасягнуць прасвятлення $i$ вярнуица ў свет, "Крыніца" 1997, № 6 (32), c. 94 . 
Па-другое, прага пошуку вымагае вылучэння вагомага, найістотнейшага, або, па-разанаўску кажучы, рэч у сабе. Нездарма ж японская паэтыка разлічвала на сустрэчны рух думкі-сузірання чытача: Ластаўкі, выпадкова // мне ў чарку з віном не ўкіньце // глебы драбок!15. Па-трэцяе, праз кантраст сэнс светастварэння пазнаецца раптойным, нечаканым спасціжэннем прыроднага хараства (напрыклад, прыгожая ў сваёй квецені сакура), дзе пануе суладдзе колеру і водару. Найперш - сакура, яе квецень (г.зн. унутрана-вабнае), вонкава ж - т.зв. "сезоннае" слова: Сакурь зацвілі - / i ночь / мінулі ў наўколлі16. Па-чацвёртае, бескампрамісны дыялог з сабою як праява самотнага пачування. Сам сябе называючы "самотнікам", Басё уммеў падкрэсліць бясцэнны дар жыцця, прыродную прыгажосць, якімі наталяўся, каб тварыць. Прычым абодва творцы пачуваюць сябе не столькі самотнікамі, колькі самадастатковымі: Тады зразумееце мае вершы, / калі заначуеце ў полі / пад сцюжньм ветрам ${ }^{17}$. Больш за тое, гэта спасціжэнне зусім іншай сістэмы вобразаў, ладу мыслення і ўяўленняў, эмацыянальнага напружання, паэтыкі - усяго нацыянальна-адметнага адпаведна кожнай літаратуры. Так, у адрозненне ад еўрапейскай літаратуры, японцы аддаюць даніну менавіта лірычнай паэзіі, у строгім сюжэце бачаць пячатку вульгарнасці, а імправізацыю расцэньваюць як само сабою зразумелае, а не нейкі асобны дар. Або, як прамаўляе старажытная японская прыказка: нявыказаныя словы гэта кветкі цішыні. Бо сузіранне прыгожага як нечага адзіна дадзенага, свяшчэннага і яго штрыхавая фіксацыя - святая справа японца. Мудрасць старажытнага Усходу патанае ў разанаўскіх перастварэннях-перакладах хоку японскага паэта Мацуа Басё.

Беларусь мяне збеларушвае, - так пранікнёна сказаў аднойчы ўкраінскі паэт Мікола Братан. Так панавіта і вылучна па-беларуску мог бы сказаць пра сябе і неўтаймаваны беларускі паэт Рыгор Барадулін, які пераклаў творы 30-ці рознамоўных паэтаў пра Беларусь і сэнсава-змястойна ўклаў словы любові ў кнігу пад слаўнай вокладкай "Беларусь мяне збеларушвае" ${ }^{18}$. Р. Барадулін - арыгінальны перакладчык-інтэрпрэтатар: ён перакладаў з 37 моў свету (паасобныя

\footnotetext{
15 Тамсама, с. 94.

16 Тамсама.

17 Тамсама, с. 100.

18 Беларусь мяне збеларушвае. Словы любові, пер. 3 розных моў Р. Барадуліна, Мінск 1993.
} 
творы У. Шэкспіра, Дж. Байрана, Р. Кіплінга, Р. Бёрнса, Ж.-Б. Мальеpa, А. Рэмбо, А. Міцкевіча, Т. Шаўчэнкі, А. Пушкіна і інш.; асобнымі выданнямі выйшлі "Слова пра паход Ігаравы", творы Я. Райніса, А. Хаяма, Г. Містраль, С. Вальехі, Б. Пастарнака, М. Шагала, А. Вазнясенскага, I. Драча, К. Шэрмана, К. Лендоэра і інш). Творы самога Р. Барадуліна перакладзеныя ці не на 40 мой свету. Аднак наўрад ці зайздросная роля кожнага ахвярніка-перакладчыка барадулінскіх твораў. Бо самабытны барадулінскі талент ведае цвёрдую цану крэўнаму беларускаму слову, з паганскай багавейлівасцю вяртае яму спаконвечнае. Так, быць беларусам, пакуль вакол, па-барадулінску кажучы, азёрна, борна, гойна, пакуль над вачыма неба, ад жаўранкаў ажаўранелае. Але якім чынам перакладчыку можна эстэтычна поўна перадаць, а галоўнае - успрыняць іншамойнаму чытачу перакладзеную барадулінскую квяцістую метафару?.. Цяжка ўявіць у эквівалентным перакладзе паэтаву ўстойлівую генітыўную метафару (сониакрыль жаўранак кахання, змяркання маразявае віно, попел вякоў і інш.). Для іншамоўнага перакладчыка ўнікальнымі выглядаюць і барадулінскія Псалмы (асабліва Псальмы Давідавы), не ўпрыгожаныя ўрачыстай стараславянскай лексікай, а менавіта насычаныя беларускімі рэаліямі (удзячнасць за араллю і пушчу; шанаванне свайго Бога; гонар за славутую памяркойнасць і інш.), дзе спалучаецца нацыянальнае і агульначалавечае, дзе палоняць выключна беларускія філасофска-лірычныя радкі з афарыстычнай падсветкай: Чалавека Бог кінуў у гэтым свеце ${ }^{19}$. Урэшце, метафара выступае ў самога "караля метафары" Р. Барадуліна як нацыянальна-культурны кампанент. У пераствораных псалмах Р. Барадуліна, дзе паяднаны біблейскі і нацыянальны пачаткі, выключна многа метафорыкі (жаўранак жадання, рэчка раічиа з берагамі, вада дапьтнасиі і інш.) і аўтарскіх наватвораў (руністьл, нарадзівеч, дапытнік, аблачьністае, дзяўчьністыя і інш.). Так, барадулінскія псалмы спрыяюць разуменню адвечных ісцін спрадвечнай біблейскай філасофіi, што павінна выратаваць беларуса ў часы адчаю. Або, як казаў сам паэт, пакуль жывв, датуль малюся Беларусі...

Творчы крэўнік Р. Барадуліна У. Караткевіч пакінуў адзін з запаветай пра сваю, Богам дадзеную беларусам зямлю, бо яна - npыўкрасная. Заўважна, у разуменні Караткевіча Беларусь - гэта найперш $\underline{\text { зямля, }} \underline{\text { край}}$, што абцяжарвае спробу адэкватнага перакладу. Вось як надзвычай прадумана, асэнсавана Караткевіч-публіцыст рас-

19 Р. Барадулін, Kcmbl, Мінск 2005, с. 84. 
крывае нацыянальную карціну свету праз канцэпт “зямля": ...nерш за ўсё мова дзесяиі мільёнаў людзей па ўсім свеце ...i, галойнае, на

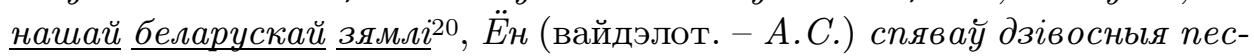
ні пра подзвігі продкаў, пра каханне $і$ смеласиь... апяваў прыгажосиь сваёй зямлі...21, Здалёку я асабліва палюбіў Беларусь $і$ яе людзей. Яна уัяуัлялася мне тады па незямному прьіўкраснай. Уся зялёная, вільготная, з азёрамі, з народам, з яго пявучай $i$ звонкай мовай, з леген-

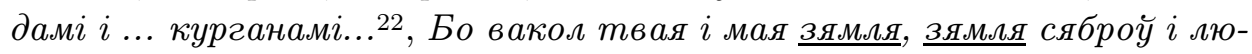

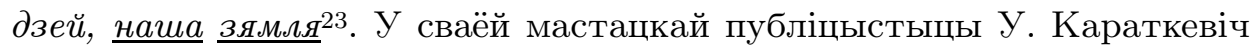
адшукваў беларускі шлях, каб адрадзіць у суайчыннікаў нацыянальны дух, урэшце, каб ісці праз нацыянальнае да агульначалавечага.

Такім чынам, пераклад люструе тыпалагічнае вывучэнне культур, у прыватнасці, праблемнае, комплекснае вывучэнне сусветнай літаратуры (i - адпаведна - беларускага кантэксту). Нацыянальна-культурны кампанент у мастацкім перакладзе слугуе выяўленню нацыянальнай самасвядомасці, расшыфройвае дылему сваё/чужое, спрыяе развіццю міжкультурнай камунікацыі.

\section{Л I T A P A T Y P A}

Алексеева И. С., Введение в переводоведение, Санкт-Петербург-Москва 2004. Багдановіч М., Поўны збор твораў: У 3 т., Мінск 1991, т. 1.

Барадулін Р., Kcmbl, Мінск 2005.

Беларусь мяне збеларушвае. Словы любові, пер. з розных моў Р. Барадуліна, Мінск 1993.

Бехер И. Р., О литературе и искусстве, Москва 1981.

Гачечиладзе Г., Художественный перевод и литературнье взаимосвязи, Москва 1980.

Івашын В. У., У кантэксие мастацкіх культур, "Полымя" 1998, № 12.

Караткевіч У., Збор твораў: У 8 т., Мінск 1991, т. 8, кн. 2.

Латышев Л. К., Перевод: теория, практика и методика преподавания, Москва 2003.

Лилова А., Введение в общую теорию перевода, Москва 1985.

20 У. Караткевіч, Збор твораў: У 8 т., Мінск 1991, т. 8, кн. 2, с. 284.

21 Тамсама, с. 285.

22 Тамсама, с. 9.

23 Тамсама, с. 331. 
Рагойша В., Пераклад як наџыляутвваральны фактар, "Беларусіка = Albaruthenika", кн. 1, Мінск 1993.

Туркоў Г., Дасягнуиь прасвятлення $i$ вярнуциа д̆ свет, "Крыніца" 1997, № 6 (32).

Чарота I., Пошук спрадвечнай існасчі: Беларуская літаратура XX стагоддзя ў прачэсах начьиянальнага самавызначэння, Мінск 1995.

Шаблоўская I. В., Сусветная літаратура ў беларускай прасторы: Рэиэпџыия. Тыпалогія. Кантакты, Мінск 2007.

S T R E S Z Z E N I E

KOMPONENT NARODOWO-KULTUROWY I KOMUNIKACJA

MIĘDZYKULTUROWA

Przekład artystyczny jest najbardziej reprezentatywnym rodzajem kontaktów (dialog, polilog) między literaturami narodowymi. W artykule omówiono zagadnienie elementu narodowego w tłumaczeniach utworów literackich na język obcy. Wykorzystano przekłady Maksima Bagdanovicha, Rygora Baradulina, Alesya Razanava i Vladimira Karatkevicha. Zwrócono uwagę na funkcję komunikatywną przekładu artystycznego.

Słowa kluczowe: składnik narodowościowo-kulturowy, komunikacja międzykulturowa, przekład literacki, kontekst, twórczość, specyfika narodowościowa, literatura narodowa.

\author{
S U M M A R Y
}

\title{
NATIONAL-CULTURAL COMPONENT AND INTERCULTURAL COMMUNICATION
}

Artistic translation is one of the most productive types of relation (dialogue, polilogue) of national literatures. In the article the author analyzes the question of national element in the translation of literature into foreign languages. The translations of Maksim Bagdanovich, Rygor Baradulin, Ales Razanav i Vladimir Karatkevich have been taken into consideration. Special attention is devoted to communicative function of artistic translation.

Key words: national-cultural component, intercultural communication, literary translation, context, literary work, national idiosyncrasy, national literature. 